DOI: https://doi.org/10.31933/dijdbm.v2i2 Received: 29 December 2020, Revised: 20 January 2021, Publish: 4 March 2021

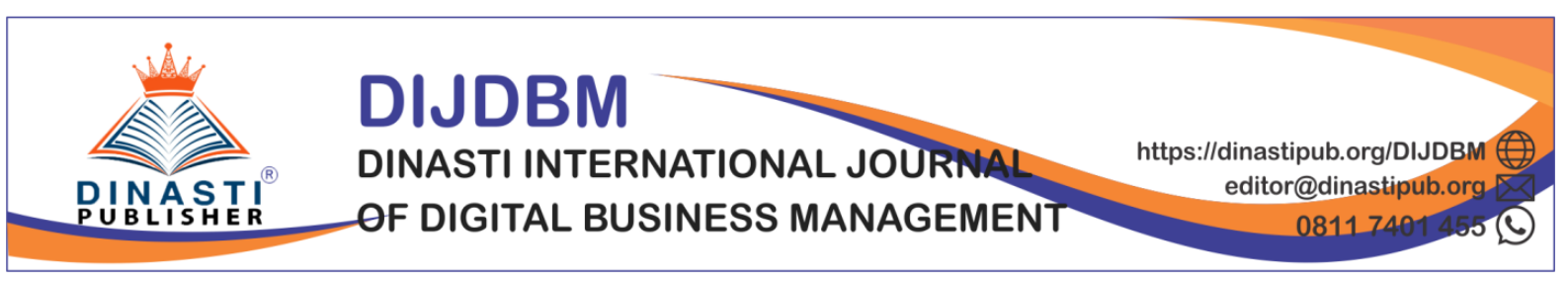

\title{
THE IMPACT OF LEADERSHIP STYLE, TRAINING AND ORGANIZATIONAL CULTURE RELATED TO THE EMPLOYEE PERFORMANCE AT BHAYANGKARA BRIMOB HOSPITAL, DEPOK
}

\author{
Fiky Trisna Nilasari ${ }^{1}$ Kasmir $^{2}$ \\ ${ }^{1)}$ Universitas Mercu Buana, Jakarta, Indonesia, fikytrisnanilasari@gmail.com \\ ${ }^{2)}$ Universitas Mercu Buana, Jakarta, Indonesia, kasmir@mercubuana.ac.id
}

\section{Corresponding Author: Fiky Trisna Nilasari}

\begin{abstract}
The intention of this research was to identify and reveal those impacts from leadership style, training, and organizational culture towards the employee performance of Bhayangkara Brimob Hospital at Depok. This research was included in quantitative research with causal method through cross-sectional methods to see the correlations between variables. The research population was all Medical Staff of Bhayangkara Brimob Hospital at Depok, with a total of 197 employees, while the sample in this research was 130 employees (through Slovin 5\% error tolerance). The data collection method in this research used a review of damage and a field review, while the method of data analysis used multiple linear regression analysis to examine the hypothesis. The results showed that the leadership style, training, and organizational culture both partially and simultaneously affect the employee performance of the Bhayangkara Brimob Hospital at Depok.
\end{abstract}

Keywords: Leadership style, training, organizational culture, employee performance.

\section{INTRODUCTION}

Human resources are the central figures in the organization, so the management activities run well and perfectly, the organization should have knowledgeable and highly skilled employees and efforts to manage the company optimally then the employee performance could increase. If the organization wants to have a qualified human resources, then the organization needs to be lead by someone who has a good leadership character in organization.

Set up from the pre-survey results which conducted by the author, it was found based on the data obtained by the HR department of Bhayangkara Hospital which showed if there was a phenomenon occurred around the year of 2014, namely a very significant decrease in the number of patients from 1,896 patients to 1,158 patients and a decrease in the number of patients the following year to 1,028 . This decline phenomenon was very significant due to a change in leadership (Head of the Hospital), the impact of this leadership transformed 
resulting in a decrease in the quality of services, health facilities and a decrease in the performance of hospital employees.

Table 1. Data of the number of Patients at Bhayangkara Hospital, Depok.

\begin{tabular}{|c|c|c|}
\hline No. & Year & Patient Amount \\
\hline 1 & $2011-2012$ & 1,669 Patients \\
\hline 2 & $2013-2014$ & 1,896 Patients \\
\hline 3 & $2015-2016$ & 1,158 Patients \\
\hline 4 & $2017-2018$ & 1,028 Patients \\
\hline
\end{tabular}

Next further pre-survey the authors gathered the data regarding the training at Bhayangkara Brimob Hospital at Depok, from those data were explained the comparison between employees before and after training was very significant, there were positive reactions from the participants who were involved in the training, it shows from every employee who took part in the training could improve self-competence respectively, from these scoring evaluation results, there was a significant increase in scoring, just like what the authors got through data from the HR department.

Table 2. Pre-survey data of Training at Bhayangkara Hospital, Depok

\begin{tabular}{|llcccc|}
\hline No & \multicolumn{1}{c}{ Type of Training } & Year & $\begin{array}{c}\text { T otal } \\
\text { Participants }\end{array}$ & $\begin{array}{c}\text { Value before } \\
\text { Training }\end{array}$ & $\begin{array}{c}\text { Value after } \\
\text { Training }\end{array}$ \\
\hline 1 & Inpatient management training & 2015 & 25 people & 55 & 85 \\
2 & BTCLS & 2016 & 15 people & 63 & 90 \\
3 & Effective communication training & 2017 & 20 people & 58 & 88 \\
4 & Basic surgery training & 2018 & 20 people & 53 & 80 \\
\hline 5 & PMKP & 2018 & 15 people & 65 & 85 \\
\hline
\end{tabular}

Organizational culture in the hospital to encourage the employee productivity is quite regular from each year, it could be seen that to regulate the attendance pattern of employees at Bhayangkara Hospital Depok, the rules for morning briefiengs and checkings of all employees, then the Bhayangkara Brimob Hospital Depok also creates the rules for leave off limits, permits or what alpha, if the employee exceeds the permit, leave, or absenteeism limit, it would be excuses for finest such as reducing work performance points and having an impact on reducing the wage/salary bonus, based on the graphics below it will be seen that no one has exceeded the maximum employee absenteeism limits but then the permits have increased in the last 3 years and the total absence is still quite large.

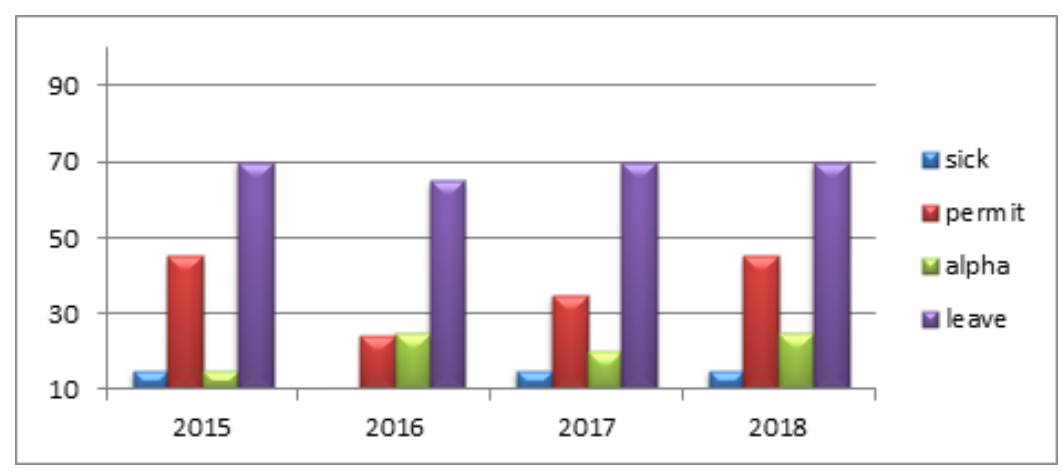

Figure 1. Graphics of Employee Attendance at Bhayangkara Hospital, Depok. 
According to the description above, the author sees or observes and tries to discover and discuss related to the influence of leadership style, training, and organizational culture on employee performance as the main factors in this discussion with the title: "The Impact of Leadership Style, Training and Organizational Culture related to the Employee Performance at Bhayangkara Brimob Hospital, Depok".

\section{LITERATURE REVIEW Leadership Style}

Leadership is the ability to influence a group to achieve goals. According to Robbins \& Judge (2011), the leadership style is a set of characteristics used by leaders to influence the subordinates, then the organizational goals would be achieved or it could be said that leadership style is a pattern of behavior and strategies which are preferred and often implemented by leaders. The Leadership style is influenced by 2 dimensions and indicators, namely participatory and laisser faire (Isjoni, 2010).

\section{Training}

Training is an activity designed to evolve human resources through a series of planned identification, assessment and learning activities. Training is a process of teaching basic skills needed by new employees or existing employees to carry out their work so the employee would be able to achieve excellent work results in future (Dessler, 2011; Pratama, 2011 in Laetemia 2018). Training dimensions and its indicators according to Rivai (2009), specifically training materials, training methods, trainers (instructors), training participants and training facilities.

\section{Organizational Culture}

Organizational culture is often defined as values, symbols that are shared and obeyed by an organization so the members of the organization would feel unity of family and create a different condition from other organizations (Irnawati \& Prasetyo, 2020). Organizational culture could also be interpreted as standard values of human resources in carrying out their obligations and behavior within the organization (Susanto, 1997 in Sudaryono, 2014). There are 7 dimensions of organizational culture, such as innovation \& risk taking, attention to detail, outcome orientation, people orientation, team orientation, aggressiveness and stability. (Robbins \& Coulter, 2010).

\section{Employee Performance}

According to Maharjan in Aima, et. al. (2017) performance is the result that is achieved because they are motivated by work and satisfied with the work that they have done. Furthermore, Sedarmayanti (2017: 54) in Alfiyah \& Riyanto (2019) reveals that the increase in employee performance could be seen from the increase in achievement of organizational that could achieve their expected goals. The indicators for sizing up employee performance are quality, quantity, timeliness, effectiveness, independence, cooperation ability, work commitment and work assessment (Robbins \& Judge, 2011). 


\section{Previous Research}

Agusta \& Susanto (2013), Wasahua (2017) found that the training has a positive and significant affect towards employee performance. Fitra (2017) found that the leadership style, organizational culture and training have a positive and significant affect on employee performance. Meanwhile, Trang (2013) found that leadership style has none significant affect towards the employee performance. Sandjaja (2015) were also found that leadership style and organizational culture had none impact on employee performance.

\section{Theoretical Framework}

According to these phenomena, the research purposed and previous research that has been mentioned, theoretical framework from this research could be described as follows:

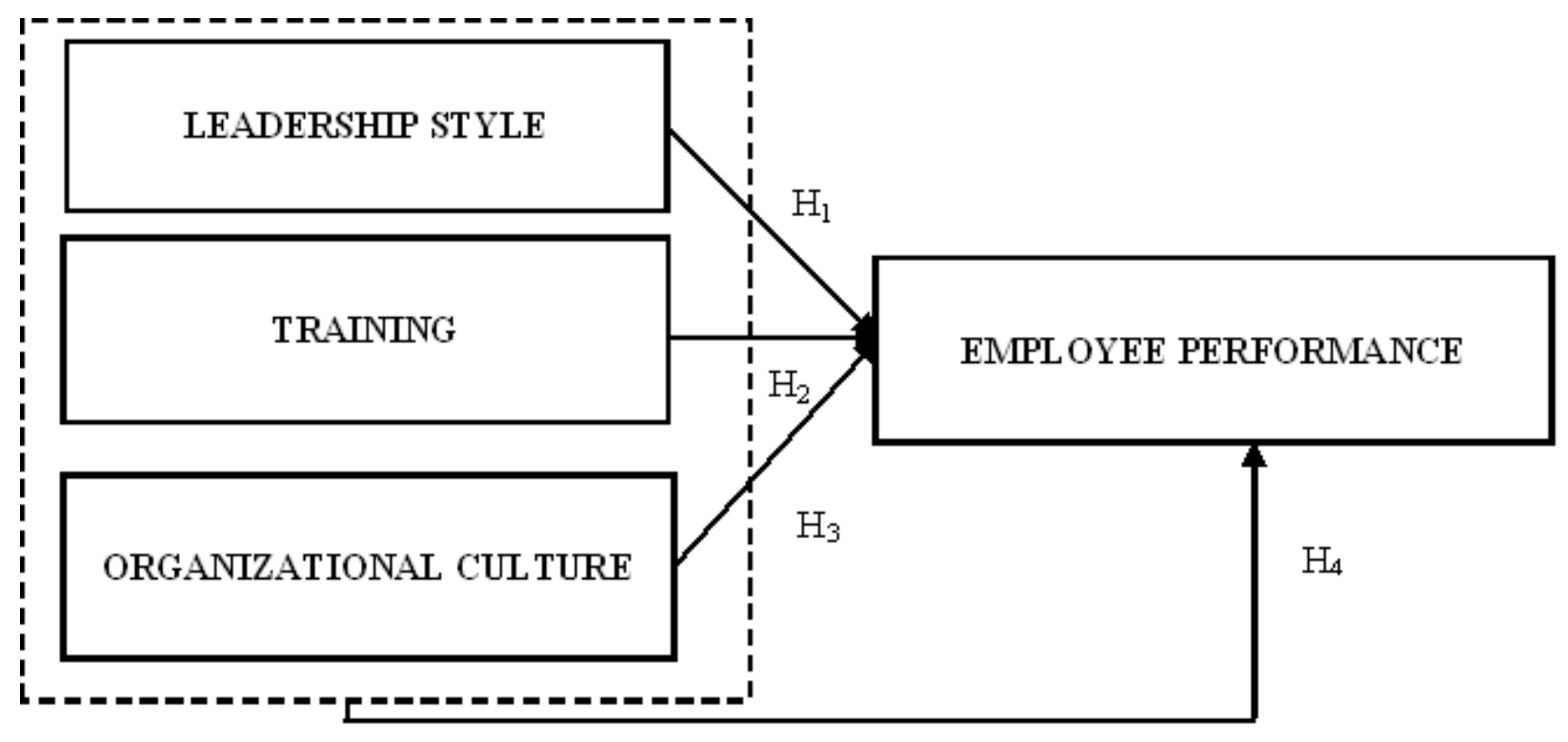

Figure 2. Theoretical Framework

\section{Hypothesis}

According to these theoretical framework which has been described, the authors could formulate the research hypothesis as in belows:

1) Hypothesis 1 (H1): Leadership has significant affect on employee performance.

2) Hypothesis 2 (H2): Training has significant affect on employee performance.

3) Hypothesis 3 (H3): Organizational culture has significant affect on employee performance.

4) Hypothesis 4 (H4): Leadership, training, organizational culture, simultaneously significant towards the employee performance. 


\section{RESEARCH METHODS}

According to this research, the author used quantitative and causal research because the author need to analyze the numerical data from the survey research. The design used by the researcher is descriptive correlative which aims to drawn the correlations between the independent variable and dependent variable. The researchers also used a cross-sectional approach or method to see how far the connection between those variables such as leadership, training, and organizational culture towards employee performance. The research population was all Medical Staff of Bhayangkara Brimob Hospital, Depok with totalling of 197 employees, while the research sample was 130 employees (Slovin, 5\% error tolerance). The data collection method used in this research was a literature review and field review, while the method of data analysis used the multiple linear regression analysis to examine the hypothesis.

\section{RESULT AND DISCUSSION Descriptive Analysis of Respondents}

According to the answers from questionnaire received, it could be seen that the descriptive identities of the majority of respondents are female (56.15\%), ages 31-40 years old $(43.08 \%)$ and have an undergraduate degree $(53.85 \%)$. This illustrates that if the majority of medical employees who work at Bhayangkara Brimob Hospital Depok were women who are still in productive age and have expertise knowledge in the health sector.

\section{Validity and Reliability Test}

Based on the results of the validity test, it is known that all indicators of the variables of leadership style, training, organizational culture, and employee performance have a value range of 0.207 to 0.931 , so they are declared valid $(>0.172)$.

Table 3. Validity Test Results

\begin{tabular}{|lccc|}
\hline \multicolumn{1}{|c}{ Indicator Code } & r count & Terms & Information \\
\hline LS01-LS07 & $0.768-0.912$ & $>0.172$ & Valid \\
\hline T01-T14 & $0.391-816$ & $>0.172$ & Valid \\
\hline OC01-OC06 & $0.765-0.931$ & $>0.172$ & Valid \\
\hline EP01-EP14 & $0.207-0.477$ & $>0.172$ & Valid \\
\hline
\end{tabular}

Based on reliability test results, it is known that all research variables have a Cronbach's Alpha value between 0.661 to 0.805 , so they were declared reliable (>0.6).

Table 4. Reliability Test Results

\begin{tabular}{|lccc|}
\hline \multicolumn{1}{|c}{ Variable } & Cronbach's Alpha & Terms & Information \\
\hline Leadership Style & 0.800 & $>0.6$ & Reliable \\
\hline Training & 0.764 & $>0.6$ & Reliable \\
\hline Organizational Culture & 0.805 & $>0.6$ & Reliable \\
\hline Employee Performance & 0.661 & $>0.6$ & Reliable \\
\hline
\end{tabular}




\section{Classic Assumption Test}

Based on these normality assumption test, the Sig. of the four variables mentioned above, have more than the value of $\alpha=0.05$ and the KScount value $<$ KStable value (1.35 / $\sqrt{ } 130=1.18)$, so it could be concluded that the data which examine has a normal data distribution.

Table 5. Normality Assumption Test Results

\begin{tabular}{|c|c|c|c|c|c|}
\hline \multicolumn{6}{|c|}{ One-Sample Kolmogorov-Smirnov Test } \\
\hline & & Leadership Style & Training & $\begin{array}{c}\text { Organizational } \\
\text { Culture }\end{array}$ & $\begin{array}{c}\text { Employee } \\
\text { Performance }\end{array}$ \\
\hline \multicolumn{2}{|l|}{$\mathrm{N}$} & 130 & 130 & 130 & 130 \\
\hline \multirow{2}{*}{$\begin{array}{l}\text { Normal } \\
\text { Parameters }\end{array}$} & Mean & 3.009 & 3.001 & 3.074 & 0.000 \\
\hline & $\begin{array}{l}\text { Std. } \\
\text { Deviation }\end{array}$ & 0.738 & 0.484 & 0.727 & 0.099 \\
\hline \multicolumn{2}{|c|}{ Test Statistic } & 0.077 & 0.078 & 0.078 & 0.070 \\
\hline Asymp. Sig. ( & 2-tailed) & $.056^{\circ}$ & $.051^{\mathrm{C}}$ & $.053^{\circ}$ & $.200^{\mathrm{c}, \mathrm{d}}$ \\
\hline \multicolumn{6}{|c|}{ a. Test distribution is Normal. } \\
\hline \multicolumn{6}{|c|}{ b. Calculated from data. } \\
\hline \multicolumn{6}{|c|}{ c. Lillief ors Si gnificance Correction. } \\
\hline \multicolumn{6}{|c|}{ d. This is a lower bound of the true significance. } \\
\hline
\end{tabular}

Based on these multicollinearity assumption test, the VIF value of each variable was less than 10. Thus, it could be interpreted that these data did not occur multicollinearity.

Table 6. Multicollinearity Assumption Test Results

\begin{tabular}{|c|c|c|}
\hline \multicolumn{3}{|c|}{ Coefficients $^{\mathrm{a}}$} \\
\hline \multirow{2}{*}{ Model } & \multicolumn{2}{|c|}{ Collin earity Statistics } \\
\hline & Tolerance & VIF \\
\hline (Constant) & & \\
\hline Leadership Style & 0.889 & 1.124 \\
\hline Training & 0.911 & 1.098 \\
\hline Organizational Culture & 0.969 & 1.032 \\
\hline
\end{tabular}

Based on these heteroscedasticity assumption test results, it could be seen that there is no clear pattern such as the dots spread above and below the number 0 on the Y axis, so the dots spread randomly and did not form a certain pattern. Thus, it could be interpreted that these data obtained was free of heteroscedasticity. 


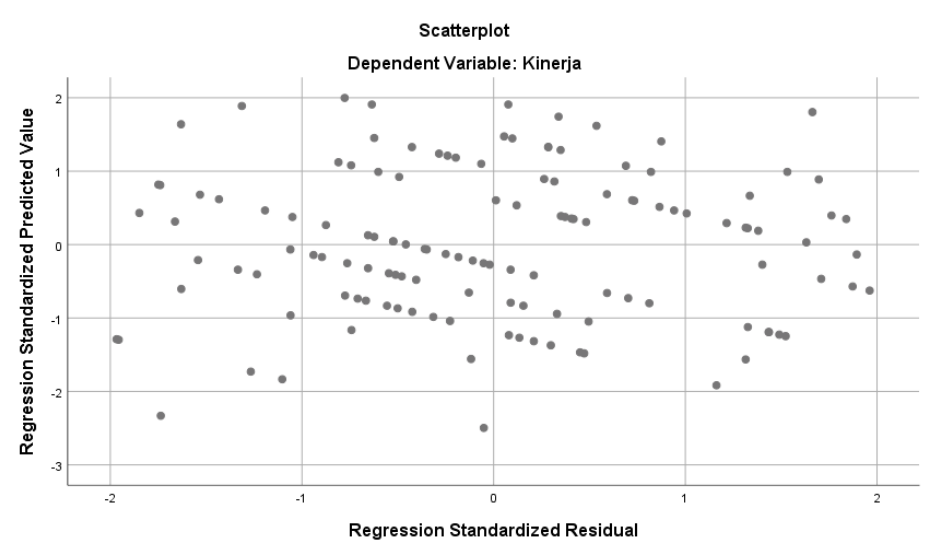

Figure 3. Heteroscedasticity Test Results

\section{Multiple Linear Regression Analysis}

According to the F-test, it is known that the value of $\mathrm{F}=108.099$, and Sig. $=0.000$ $<0.05$, so it could be interpreted that leadership style, training and organizational culture simultaneously have a significant affect on employee performance with a large influence of 71.4\% (Adjusted R2 = .714).

Table 7. F-Test Results

\begin{tabular}{|l|l|r|r|r|r|c|}
\hline \multicolumn{7}{|c|}{ ANOVA $^{\mathbf{a}}$} \\
\hline \multicolumn{2}{|c|}{ Model } & $\begin{array}{c}\text { Sum of } \\
\text { Squares }\end{array}$ & \multicolumn{1}{c|}{ df } & $\begin{array}{c}\text { Mean } \\
\text { Square }\end{array}$ & F & \multicolumn{1}{c|}{ Sig. } \\
\hline \multirow{2}{*}{1} & Regression & 3.270 & 3 & 1.090 & 108.099 & $.000^{\text {b }}$ \\
\cline { 2 - 7 } & Residual & 1.271 & 126 & 0.010 & & \\
\cline { 2 - 7 } & Total & 4.541 & 129 & & & \\
\hline
\end{tabular}

Table 8. $\mathbf{R}^{2}$ Test Results

\begin{tabular}{|l|c|r|r|r|r|}
\hline \multicolumn{7}{|c|}{ Model Summary $^{\mathbf{b}}$} \\
\hline Model & $\mathrm{R}$ & R Square & Adjusted R Square & Std. Error of the Estimate & Durbin-Watson \\
\hline 1 & $.849^{\mathrm{a}}$ & 0.720 & 0.714 & 0.100 & 1.956 \\
\hline
\end{tabular}

According to the t-test results, it is known that leadership style, training, and organizational culture partially have a positive and significant affect on the performance of medical staff at Bhayangkara Brimob Hospital, Depok (t-count> 1.98, and Sig. 0.000). The regression equation is $\mathrm{Y}=2.375+0.146 \mathrm{X} 1+0.139 \mathrm{X} 2+0.079 \mathrm{X} 3+\mathrm{e}$.

Table 9. Multiple Linear Regression Results

\begin{tabular}{|c|c|c|c|c|c|c|}
\hline \multicolumn{7}{|c|}{ Coefficients ${ }^{\mathrm{a}}$} \\
\hline & \multirow{2}{*}{ Model } & \multicolumn{2}{|c|}{$\begin{array}{l}\text { Unstandardized } \\
\text { Coefficients }\end{array}$} & \multirow[t]{2}{*}{ t } & \multirow{2}{*}{ Sig. } & \multirow{2}{*}{ Keterangan } \\
\hline & & B & Std. Error & & & \\
\hline \multirow[t]{4}{*}{1} & (Constant) & 2.375 & 0.069 & 34.226 & 0.000 & \\
\hline & Leadership Style & 0.146 & 0.013 & 11.506 & 0.000 & Positive \& Significant \\
\hline & Training & 0.139 & 0.019 & 7.247 & 0.000 & Positive \& Significant \\
\hline & Organizational Culture & 0.079 & 0.012 & 6.415 & 0.000 & Positive \& Significant \\
\hline
\end{tabular}




\section{Inter-Dimensional Correlation Analysis}

According to the inter-dimensional correlation analysis results, it was found that the greatest correlation value between the dimensions in the leadership style variable and the employee performance variable was the participatory dimension with the effectiveness dimension, such as 0.603 and was included in the strong level category. The greatest correlation value between the dimensions in the training variable and employee performance variable is the training method dimension with the quality dimension which is 0.525 and falls into the moderate level category. The greatest correlation value between the dimensions in the organizational culture variable on the employee performance variable is the capability dimension with the quality dimension, namely 0.419 and were included in the moderate level category.

\section{Discussion}

The hypothesis test result shows that $\mathrm{H} 1$ was accepted and it was interpreted that leadership style has a positive and significant affect on employee performance. These results were in line with the research from Wasahua (2017) and Fitria (2017). This could be related to the better the leadership style from a leader and the better the criteria of a leader in giving a positive influence to an organization or agency, the managerial impact towards the employee performance would also increase and improve. Meaning that the leader demand to capable to develop and give good authority in order to achieve goals in the organization / agency. If it is related to the correlation between dimensions, a participatory attitude in leadership style is needed to support the improvement of employee performance, in order to achieve a goal expected by an organization or related institution.

The hypothesis results show that $\mathrm{H} 2$ was accepted and it was concluded that training has a positive and significant affect on employee performance. These results were in line with the research of Agusta \& Susanto (2012), Wasahua (2017), and Fitria (2017). This shows that training would improves technical, theoretical, conceptual and moral abilities of employees so employees would be able to achieve optimal work results later then the employees are eager to work for an organization or agency. Training is the process of teaching the basic skills needed by new employees or existing employees to carry out their jobs. If its related with the results of the correlation between dimensions, the training method used could improve the quality of employee performance in achieving the employees' measurement value.

The hypothesis results show that $\mathrm{H} 3$ was accepted and it was concluded that organizational culture has a positive and significant affect towards the employee performance. These results were in line with Fitria's research (2017). Meaning if the better the organizational culture, the better the performance of the Medical Staff at Bhayangkara Brimob Hospital, Depok. If its associated with the correlation between dimensions, capabilities in organizational culture are very necessary for any increase in performance, specifically in the quality of employees of an organization or to related institution.

The hypothesis result shows that H4 was accepted and was interpreted that leadership style, training, and organizational culture simultaneously affect the employee performance. These results were in line with Fitria's research (2017). This shows that through this 
simultaneous influence, it indicates that there is an attachment to support the improvement of employee performance, therefore it would be great if the human resource team at Bhayangkara Brimob Hospital Depok more attentive towards these variables.

\section{CONCLUSION AND SUGGESTION Conclusion}

Based on these research results and the discussion of the data analysis which carried out by the author, these interpreted that could be drawn based on hypothesis proven which could be form, namely:

1) Leadership style has a positive and significant affect on employee performance, meaning that the better the leadership style offered it would improve the performance of the Medical Staff of the Bhayangkara Brimob Hospital Depok.

2) Training has a positive and significant affect on employee performance, meaning that the better the training and the more organized the training is, it would enhance the performance of the Medical Staff at Bhayangkara Brimob Hospital Depok.

3) Organizational culture has a positive and significant affect on employee performance, meaning that the better the developing of organizational culture, the better innovation would also advance the performance of the Medical Staff at Bhayangkara Brimob Hospital Depok.

4) Leadership style, training, and organizational culture simultaneously have a significant affect on employee performance, meaning that the better the leadership style, training, and organizational culture which is owned then it would enhance the performance of the employees at the Medical Staff of the Bhayangkara Brimob Hospital Depok.

\section{Suggestions}

Several recommendations that could be conveyed based on these analysis that has been carried out in accordance with the research results, such as:

1) Because the leadership style affects the employee performance at the Bhayangkara Brimob Hospital, Depok, it is necessary to carry out further evaluation towards the leader performance, the evaluation of the leader performance could be done by several methods, namely through questionnaires and interviews with employees, so the leaders could evaluate themselves through the results of performance assessment survey,

2) Because the training has a significant affect on employee performance, so it is hoped that the Bhayangkara Brimob Hospital Depok will hold training for every profession that is in the scope of health services, and this training would held in accordance with the employees profession and competence, in order to encourage the employee competence.

3) Because the organizational culture has a positive and significant affect on employee performance at the Bhayangkara Brimob Hospital Depok, it is hoped that the hospital needs to continue to maintain the organizational culture that has been done so far and expected to create a new organizational culture in the form of hospital innovation in fixing the quality of health services to the public. The innovation in organizational culture would create trust and good feedback from the community to the hospital.

4) For further researchers, it is hoped that they could carry out this research wider through in-depth research towards the performance of employees in hospitals by adding another 
variables that have not been examined in this research, such as absenteeism compliance, work discipline and work safety. This research is expected to be one of the literature sources that could be used by other researchers. Through this research it is hoped that it could help them in conducting their research.

\section{REFERENCE}

Agusta, L; E. M. Susanto (2013), Pengaruh Pelatihan dan Motivasi Kerja Terhadap Kinerja Karyawan CV Haragon Surabaya. AGORA, 1 (3).

Aima, H., Adam, R., \& Ali, H. (2017). Model of Employee Performance: Competence Analysis and Motivation (Case Study at PT. Bank Bukopin, Tbk Center). Journal of Research in Business and Management, 4(11), 49-59.

Alfiyah, N., \& Riyanto, S. (2019). The Effect of Compensation, Work Environment and Training on Employees' Performance of Politeknik LP3I Jakarta. International Journal of Innovative Science and Research Technology, 4(5), 947-955.

Dessler, G. (2011). Human Resoure Management: Global Edition. Pearson Education. New Jersey.

Fitria, E. (2017). Analisis Pengaruh Kepemimpinan, Motivasi, Budaya Organisasi Dan Pelatihan Terhadap Kinerja Karyawan Non Medis Dengan Komitmen Organisasi Sebagai Variabel Intervening (Studi Klinik Spesialis Ginjal Dan Hipertensi Rasyida Medan). Tesis. Universitas Sumatera Utara.

Irnawati, J.E., \& Prasetyo, J.H. (2020). The Influence Over the Transformational of Leadership Style, the Organizational Culture, and Employee Empowerment towards Achievement of Organizational Strategies in one the Central Government Organization. International Journal of Innovative Science and Research Technology, 5(3), 917-927.

Isjoni. (2010). Pembelajaran Kooperatif. Meningkatkan kecerdasan antar peserta didik. Yogyakarta: Pustaka Pelajar.

Laetemia, S.Y. (2018). Pengaruh Pelatihan dan Pengalaman Kerja Terhadap Kinerja

Karyawan (Studi pada Kantor Badan Pusat Statistik di Maluku). Jurnal Manis, 2(1).

Rivai, V. (2009). Manajemen Sumber Daya Manusia Untuk Perusahaan Dari Teori ke

Praktik. Jakarta: Raja Grafindo Persada.

Robbins, S.P. \& Coulter, M. (2010). Manajemen Edisi Kesepuluh. Jakarta: Erlangga.

Robbins, S.P. \& Judge, T. (2011). Organizational Behavior. Fourteenth Edition. Pearson Education. New Jersey.

Sudaryono. (2014). Budaya dan Perilaku Organisasi. Jakarta: Lentera Ilmu Cendekia.

Trang, D.S. Gaya Kepemimpinan dan Budaya Organisasi Pengaruhnya Terhadap Kinerja Karyawan (Studi pada Perwakilan BPKP Provinsi Sulawesi Utara). Jurnal EMBA, 1(3), 208-216.

Wasahua, O. (2017). Pengaruh Kepemimpinan, Diklat dan Budaya Organisasi Terhadap Kinerja Pegawai Direktorat Jenderal Pembinaan Penempatan Tenaga Kerja Kemenaketrans RI. Sosio e-kons, 9(1). 